\title{
EFFECT OF VIRULENCE AND SERIAL TRANSFERS OF XANTHOMONAS CAMPESTRIS ON XANTHAN GUM PRODUCTION
}

\author{
Marcia Nitschke*; Vanessa Rodrigues \\ Laboratório de Microbiologia Agrícola e Ambiental, Instituto de Ciências Biológicas, Faculdade de \\ Agronomia, Universidade de Passo Fundo, Passo Fundo, RS, Brasil
}

Submtted: September 23, 1999; Approved: February 02, 2000

\begin{abstract}
The virulence of six Xanthomonas campestris isolates was evaluated using the percentage of lesion area of leaves in Brassica oleraceae host plant, compared to diameter of colonies, xanthan production and gum viscosity. In terms of virulence, the isolates belonged to two statistically different groups: isolates B, UPF and $\mathrm{C}_{7}$ showed values between 52 and $69 \%$, while isolates $\mathrm{CF}, \mathrm{C}$ and strain $\mathrm{B}-1459$ gave $0-30 \%$ of lesion area. Final xanthan concentration, gum viscosity and colony diameter did not correlate with virulence calculated by percentage of lesion area, showing that this parameter is not a good criterium for selection of potential xanthan producer isolates. Serial transfers of $X$. campestris isolates in host plant did not show a significant effect on "in vitro" production of xanthan or on viscosity levels, suggesting that the increasing interaction between plant and bacteria did not stimulate the increase in xanthan production and viscosity.
\end{abstract}

Key words: Xanthomonas campestris, serial transfers, virulence, xanthan

\section{INTRODUCTION}

Xanthan gum is an important microbial polysaccharide and is produced by bacteria of the genus Xanthomonas. The gum has numerous applications in many fields as a viscosifying and suspending agent $(2,5)$. Xanthomonas campestris is a plant pathogen causing black rot of crucifers, which has economic importance in crop damage (13). The virulence of Xanthomonas is partially related to the damage of the vascular system produced by blocking the nutrient supply, due to the viscosity created by the polymer (11). However, the exact role of xanthan gum in nature is not well understood.

Ramirez et al. (7) have reported that the virulence of Xanthomonas variants is influenced by the quality of the polymer produced, while Shaw et al. (10) showed that some spontaneous EPS-deficient mutants of $X$. campestris still induced disease symptoms suggesting that xanthan gum is not required for pathogenicity.

Some authors pointed out that reinoculation of bacteria in host plant affects polymer production and virulence (3) and Salcedo et al. (8) suggested the maintenance of Xanthomonas strains in host plant seeds, as it could simulate the natural habitat of bacteria and avoid the loss of important wild-type characteristics.

In this paper virulence of some Xanthomonas campestris isolates was compared with colony diameter, xanthan production and gum viscosity, to evaluate the virulence as a criterium for selection of high xanthan producer isolates and the effect of serial transfers on xanthan production.

\section{MATERIALS AND METHODS}

Microorganisms: $X$. campestris isolates were collected from infected cauliflower (CF), broccoli (B) and cabbage ( $\left.\mathrm{C}, \mathrm{C}_{7}, \mathrm{UPF}\right)$. Strain NRRL B-1459 was obtained from Northern Regional Research Laboratories (USA). The bacteria were isolated using the technique described by Schaad and Stall (9). Serial transfer experiments were performed using the UPF isolate.

\footnotetext{
* Corresponding author. Mailing address: Departamento de Ciências Fisiológicas, Instituto de Ciências Biológicas, Universidade de Passo Fundo, Campus Bairro São José., Caixa Postal 611, CEP 99001-970, Passo Fundo, RS, Brasil.
} 
Culture media: the strains were maintained on YM agar slants containing $\left(\mathrm{g} \mathrm{L}^{-1}\right)$ : yeast extract, 3; malt extract, 3; peptone, 5 ; glucose, 10; agar, 20. The production medium used for xanthan evaluation was described by Ramirez et al. (7).

Colony diameter: the diameter of the colonies was measured after $72 \mathrm{~h}$ of incubation at $28^{\circ} \mathrm{C}$ on YM agar plates. The results are the average of three replicates.

Virulence test: a concentration of $1-2 \times 10^{8} \mathrm{cfu} / \mathrm{ml}$ of each Xanthomonas isolate was prepared in YM broth. Two-months old plants of Brassica oleraceae were placed in a wet chamber for $24 \mathrm{~h}$, then the plants were spread with standardized inoculum and placed in a greenhouse for 12 days, to allow development of disease. Virulence was evaluated by the percentage of lesion area of leaves, through comparison with a standard visual scale. Five plants and one control for each isolate were tested.

Fermentation: the inoculum was prepared in YM medium by transferring a loop from a $24 \mathrm{~h}$ slant to $5 \mathrm{ml}$ of broth and incubating for $24 \mathrm{~h}$ at $28^{\circ} \mathrm{C}$ and $160 \mathrm{rpm}$. For the gum production test, $10 \%(\mathrm{v} / \mathrm{v})$ of the inoculum was added to $90 \mathrm{ml}$ of the production medium in a 500ml Erlenmeyer flask grown for 72 $\mathrm{h}$ at $28^{\circ} \mathrm{C}$ and $200 \mathrm{rpm}$. The experiment was conducted with three replicates.

Serial transfers: the UFP isolate was inoculated into plants as described in the virulence test. After development of disease, the lesion area was removed from leaves and the bacteria were recovered using the technique described by Schaad and Stall (9) using SX and GYCA agar plates. The plates were incubated at $28^{\circ} \mathrm{C}$ for 3-5 days. Characteristic colonies were selected, submitted to identification tests and maintained on YM agar slants at $5^{\circ} \mathrm{C}$. The new isolates were submitted to the fermentation test and the final broth was used for viscosity and xanthan measurements. The new isolates were also prepared for reinoculation in host plant as described above.

Analytical measurements: final broth was heated at $80^{\circ} \mathrm{C}$ during 30 minutes, diluted with five volumes of water and centrifuged (7000 g; 40 minutes) to achieve complete cell removal. $1 \% \mathrm{KCl}(\mathrm{w} / \mathrm{v})$ was added to the supernatant and xanthan gum was recovered by addition of three volumes of $96^{\circ}$ ethanol. The precipitated gum was left in an oven at $50^{\circ} \mathrm{C}$ and in a dessecator at room temperature until constant weight. Viscosity measurements were performed using $1 \%(\mathrm{w} / \mathrm{v})$ gum solutions with $1 \% \mathrm{KCl}$, in a Rheo viscometer (MLW) using 0.1 tube and

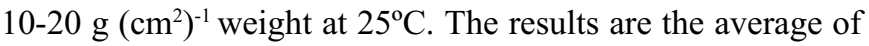
three replicates.

\section{RESULTS AND DISCUSSION}

Table 1 shows the results for the five isolates and strain B1459. All colonies were mucoid and opaque yellow in color, and isolates UPF and $\mathrm{C}_{7}$ gave the highest diameter after incubation. Three isolates had small colony diameter and strain B-1459 showed an intermediate value.
The virulence calculated by percentage of lesion area resulted in two statistically different groups $(\mathrm{p}<0.05)$ : isolates $\mathrm{B}$, UPF and $\mathrm{C}_{7}$ were the most virulent and showed values between 52$69 \%$, while isolates CF, C and strain B- 1459 showed $0-30 \%$ of lesion area. Strain B-1459 did not show any sign of infection during the period tested and was considered a negative control.

Xanthan concentration stayed in the range of 8.3 to $13.5 \mathrm{~g}$ $\mathrm{Kg}^{-1}$ and viscosity of the gum varied from 24 to $601 \mathrm{cP}$.

The parameters were submitted to linear regression analysis and the results indicated very low correlation $\left(\mathrm{r}^{2}<0.4\right)$ between virulence, colony diameter, xanthan, and viscosity. Although no virulence was detected, strain B-1459 produced $13.3 \mathrm{~g} \mathrm{Kg}^{-1}$ of xanthan and a solution viscosity of $127.3 \mathrm{cP}$ (Table 1).

Table 1. Comparison of Xanthomonas campestris isolates.

\begin{tabular}{ccccc}
\hline Isolates & $\begin{array}{c}\text { Colony } \\
\text { Diameter }(\mathrm{mm})\end{array}$ & $\begin{array}{c}\text { Infected area } \\
(\%)\end{array}$ & $\begin{array}{c}\text { Viscosity } \\
(\mathrm{cP})\end{array}$ & $\begin{array}{c}\text { Xanthan } \\
\left(\mathrm{g} \mathrm{Kg}^{-1}\right)\end{array}$ \\
\hline $\mathrm{B}$ & 3.5 & 69.6 & 88 & 13.5 \\
$\mathrm{UPF}$ & 6.5 & 52.0 & 24 & 10.8 \\
$\mathrm{C}$ & 3.5 & 14.1 & 223 & 8.3 \\
$\mathrm{CF}$ & 3.5 & 30.4 & 201 & 11.7 \\
$\mathrm{~B}-1459$ & 4.0 & 0 & 127 & 13.3 \\
$\mathrm{C}_{7}$ & 6.0 & 52.9 & 601 & 8.5 \\
\hline
\end{tabular}

A problem arising in screening microorganisms for polysaccharide production is the lack of suitable techniques for selection of potential strains. Cadmus et al. (1) reported that some morphological characteristics of colonies of Xanthomonas could be correlated with polymer production and pyruvic acid content. Kidby et al. (4) found that small colony variants produce gums of lower quality whereas large colonies produce higher quality gums; virulence and infrared spectra of polymers and penicillin $\mathrm{G}$ sensitivity were also suggested $(7,12)$. Ramirez et al. (7) reported some correlation between colony morphology and pathogenicity but Torrestiana et al. (12) showed that colony morphology did not correlate with the xanthan pyruvate level.

The isolates $\mathrm{C}_{7}$ and $\mathrm{C}$ showed higher viscosity and lower xanthan production. This could be explained by the quality of gums, i.e., the polymers produced by these isolates probably have different chemical characteristics that permit generation of high viscosity per polymer unit.

Ramirez et al. (7) suggested that virulence had some correlation with viscosity of fermentation broths. However, in the present work, the viscosities of extracted gums were measured because Nitschke and Thomas (6) showed that broth viscosity did not correlate with the extracted gum solution viscosity, which is an important indicator of gum quality. Our results are in agreement with those found by Torrestiana et al. (12), showing the limited value of colony diameter in screening xanthan producers our results also suggest that xanthan is not required for pathogenicity, as we isolated a non-virulent strain 
(no disease symptoms in leaves) that presente high xanthan production in vitro. A morphological differentiation in Xanthomonas isolates was reported by Kamoun and Kado (3) who described a phenotypic switching that affects virulence and in vitro polysaccharide production. These authors found that the isolates reverted to the wild type (virulent and gum producer) when reinoculated in leaves. This morphological alteration could explain the many different results obtained when xanthan and virulence were compared $(7,10,12)$. The results obtained show that virulence, calculated as percentage of lesion area, is not recommended as a criterium for the selection of high xanthan producer isolates.

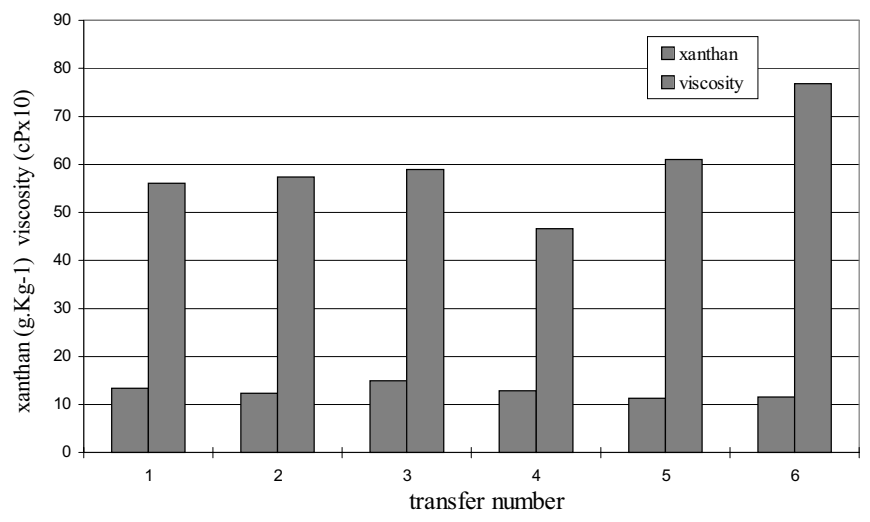

Figure 1. Influence of serial transfers of $X$. campestris on xanthan production

Fig. 1 shows evaluation of isolate UPF after 6 transfers in plant host. It can be noted that the xanthan and viscosity levels were not affected by increasing the contact between bacteria and plant. The xanthan recovered shows similar values, while viscosity increased, but not significantly $(\mathrm{P}<0.05)$. Changes in morphology were not detected during experiments, as also reported by Kamoun and Kado (3). Virulence and xanthan production capacity were maintained when isolates were on agar slants during the six months of experiments. Although a positive effect of serial transfers was not observed in the tested isolates, it is important to note that if serial transfers did not increase significantly the gum production they also did not decrease it, so the host plant could be an alternative for strain maintenance, as suggested by Salcedo et al. (8).

\section{RESUMO}

Efeito da virulência e de repasses sucessivos de Xanthomonas campestris na produção de goma xantana

A virulência de seis isolados de Xanthomonas campestris foi determinada através da porcentagem de área foliar afetada, utilizando-se como hospedeiro Brassica oleraceae, comparada com o diâmetro de colônias, viscosidade e concentração da goma produzida "in vitro". A virulência dos isolados $\mathrm{B}$, UPF e $\mathrm{C}_{7}$ variou entre $52-69 \%$, enquanto os isolados $\mathrm{CF}$ e $\mathrm{C}$ e a estirpe B-1459 apresentaram valores entre $0-30 \%$, constituindo dois grupos estatisticamente diferentes $(p<0,05)$. A concentração final e a viscosidade da goma produzida, bem como o diâmetro das colônias, não apresentaram índice de correlação significativo quando comparados com a virulência calculada pela percentagem de área foliar afetada. Portanto, o parâmetro virulência não foi considerado satisfatório como indicativo para a seleção de microrganismos produtores potenciais de goma xantana. $\mathrm{O}$ repasse sucessivo de um isolado de $X$. campestris na planta hospedeira não demonstrou um aumento significativo na xantana produzida in vitro e nos níveis de viscosidade do produto final. Este fato sugere que uma maior interação entre planta e bactéria não estimula o aumento da produção e da viscosidade da goma xantana .

Palavras-chave: Xanthomonas campestris, repasses sucessivos, virulência, xantana

\section{REFERENCES}

1. Cadmus, M.C.; Rogovin, S.P.; Burton, K.A.; Pittsley, J.E.; Knutson, C.A.; Jeanes, A. Colonial variation in Xanthomonas campestris NRRL B-1459 and characterization of the polysaccharide from a variant strain. Canadian J. Microbiol., 19:942-948, 1978.

2. Cottrell, I.W.; Kang, K.S. Xanthan gum, a unique bacterial polysaccharide for food applications. Developments in Industrial Microbiology, 19:117$131,1978$.

3. Kamoun,S.; Kado, C.I. Phenotypic switching affecting chemotaxis, xanthan production, and virulence in Xanthomonas campestris. Appl. Environm. Microbiol., 56: 3855-3860, 1990.

4. Kidby, D.; Sandford, P.; Herman, A. ; Cadmus, M. Maintenance procedures for the curtailment of genetic instability: Xanthomonas campestris NRRL B-1459. Appl. Environm. Microbiol., 33:840-845, 1977.

5. Margaritis, A.; Pace, G.W. Microbial polysaccharides. In: Blanch, H.W.; Drew, S.; Wang, D.I.C. (eds). Comprehensive biotechnology. The practice of biotechnology: current commodity products. Pergamon Press, New York, 1985, p.1005-1044.

6. Nitschke, M.; Thomas, R.W.S.P. Xanthan gum production by wild-type isolates of Xanthomonas campestris. World J. Microbiol. Biotechnol., 11: 502-504, 1995.

7. Ramirez, M.E.; Fucikousky, L.; Garcia-Jimenez, F.; Quintero, R.; Galindo, E. Xanthan gum production by altered pathogenicity variants of Xanthomonas campestris. Appl. Microbiol. Biotechnol., 29: 5-10, 1988.

8. Salcedo,G., Ramirez, M.E., Flores, C., Galindo, E. Preservation of Xanthomonas campestris in Brassica oleraceae seeds. Appl. Microbiol. Biotechnol., 37:723-727, 1992.

9. Schaad, N.W.; Stall, R.E. Xanthomonas. In: Schaad, N.W. (eds). Laboratoryguide for identification of plant pathogenic bacteria. American Phytophatological Society, Minnesota, 1988, p.81-94.

10. Shaw, J.J.; Settles, L.G.; Kado, C.I. Transposon Tn4431 mutagenesis of Xanthomonas campestris pv. campestris : characterization of a nonpathogenic mutant and cloning of a locus for pathogenicity. Molecular Plant Microbe Interactions, 1: 39-45, 1988.

11. Sutton, J.C.; Williams, P.H. Comparison of extracellular polysaccharide of Xanthomonas campestris from culture and from infected cabbage leaves. Canadian J. Botanic, 48: 645-651, 1970

12. Torrestiana, B.; Fucikovsky, L.; Galindo, E. Xanthan production by some Xanthomonas isolates. Lett. Appl. Microbiol., 10: 81- 83, 1990.

13. Williams, P.H. Black rot: a continuing threat to world crucifers. Plant Dis., 64: 736-742, 1980 